\title{
THE EFFECTS OF LOW METAL LEVELS ON A CLONAL HYDROID
}

\author{
A. R. D. STEBBING \\ N.E.R.C. Institute for Marine Environmental Research, \\ Citadel Road, Plymouth PL1 3DH, England
}

(Figs. 1-6)

\begin{abstract}
A sensitive and precise bioassay has been developed, using the colonial hydroid Campanularia flexuosa, for measuring the sublethal effects of marine contaminants in terms of the inhibition of colonial growth rate. A single clone can be cultured simply in the laboratory for indefinite periods. Thresholds of sensitivity to three metals in 11-day experiments were $\mathrm{Hg}^{2+} 1 \cdot 6-1 \cdot 7 \mu \mathrm{g} / \mathrm{l}, \mathrm{Cu}^{2+} 10-13 \mu \mathrm{g} / \mathrm{l}, \mathrm{Cd}^{2+} 110-280 \mu \mathrm{g} / \mathrm{l}$. Observations on the development of the hydroid's response with time shows that sensitivity increases linearly at first, but during the second week the metals have a transitory stimulatory effect on colonial growth rate which is known as the ArndtSchulz Effect.
\end{abstract}

\section{INTRODUCTION}

We frequently require sensitive bioassay techniques with which to study the effects of marine contaminants at environmentally realistic concentrations. Unfortunately, it is difficult to achieve sensitivity and precision in an organism amenable to indefinite periods of laboratory culture. Results from different laboratories are often extremely variable: $L_{5}$ O values for the same substance, using the same organism, may differ by two or even three orders of magnitude (Wilson, Cowell \& Beynon, 1975). Moreover, some of the most sensitive bioassay organisms require nutrient media, which may alter the availability and toxicity of metals by complexing them (Jones, 1964; Kamp-Nielsen, 1971; Hannan \& Patouillet, 1972) and often contain metal impurities at significant levels (Albert, 1968; Steeman Nielsen \& Wium Anderson, 1970). The object of the work reported here has been to develop a technique by which these problems might be minimized or avoided. Hydroids were chosen as bioassay organisms for a variety of reasons. They are tolerant but sensitive to small variations in their chemical environment. Techniques for growing hydroids are simple and they can be cultured under conditions of near optimal temperature, salinity and food supply, thus minimizing the errors frequent in bioassay work arising from variations in the history of the test organisms, their size, sex or physiological state. An important source of variability in all work with organisms is that inherent in the genetic material, but with hydroids this can be avoided by the use of a single clone.

Since the pioneer work of Rees \& Russell (1937) hydroids have been cultured by a number of people; for example, in America by Crowell (1957), Fulton (1962) and Braverman (1974) and in Germany by Hauenschild (1954), Kinne (1965), Werner (1968) and Karbe (1972). Despite small variations, their culture techniques are similar; colonies are grown attached to glass slides, initiated by subculturing from a parent 
colony and are usually fed with Artemia salina nauplii. Asexual reproduction of individuals results in an exponential pattern of growth in numbers of colony members that is typical of all colonial animals (Stebbing, 1971). The technique used here differs from those used previously only in scale, so that colonies can be grown for long enough periods and with sufficient replication at each treatment.

It is intended to use the method in three ways: first, to investigate the relative effects of toxic contaminants at environmental concentrations; secondly, to study the indigenous characteristics of sea water that modify metal toxicity and, thirdly, to measure the biological quality of sea water samples. In this paper the technique will be described in detail and an account given of experiments designed to test the technique using sublethal concentrations of mercury, copper and cadmium.

\section{METHODS}

\section{Culture technique}

Several species of hydroid were tried before one suitable for this work was found. Hydractinia echinata, Podocoryne carnea and Dicoryne conferta all proved difficult to subculture or grew too slowly. In June 1973 a clone of Campanularia flexuosa (Hincks, in Alder, 1856) was isolated from a pylon off Cremyll Hard in the River Tamar. It proved possible to subculture this species with better than $95 \%$ success and growth was fast; colonies grow from about 4 to 150 individuals in 2 weeks. They are grown on glass plates $\left(1 \mathrm{dm}^{2}\right)$ and are subcultured by first removing stolons and uprights (which bear the hydranths, buds and gonozooids) from parent colonies. Healthy uprights with three or more hydranths are separated, together with a length of stolon. Initially the explant is held in position against the centre of the plate by a monofilament nylon thread tied tightly around it. Attachment and early growth is rapid and the nylon threads are removed after three days. Racks, holding seven plates, are kept in 21 glass boxes maintained at $20^{\circ} \mathrm{C}$ in water baths. Each glass box is aerated with air first passed through activated charcoal and then a cotton-wool filter. The tanks are covered with Perspex sheets to exclude dust.

Stock colonies are fed two or three times a week, but during experiments and for a week beforehand they are fed daily, because there is a tendency for a slower growth rate to be maintained for a few days after daily feeding begins. Racks of colonies are immersed in a dense suspension of newly hatched Artemia salina nauplii (San Francisco Bay type, see Wickens, 1972). Their eggs are hatched in aerated round-bottom flasks $(15 \mathrm{ml}$ eggs in 31 sea water), which are maintained at $25^{\circ} \mathrm{C}$. After 2 days the nauplii are separated from their egg cases, filtered, washed and resuspended in $100 \mathrm{ml}$ of sea water. Approximately $10 \mathrm{ml}$ of this suspension is added to each glass box, giving a density of 35-40 nauplii per $\mathrm{ml}$ of sea water, in which the hydroids feed for 30 mins. This density has been checked during a number of experiments by counting the nauplii in $0.5 \mathrm{ml}$ samples of the suspension taken with a Stempel pipette and found to vary little. It is assumed that all hydranths of every colony have the opportunity to become satiated and that availability of food is not a significant cause of variation in colonial growth rates. Checks made during feeding on the numbers ingested indicated that any increase in the feeding time of $30 \mathrm{~min}$ would not result in the consumption of greater numbers of nauplii. After feeding, the racks of colonies are put in clean tanks with newly filtered sea water.

At first it was intended to maintain the stock and control colonies for all experiments in synthetic sea water, because it was thought that in the long term the composition of a synthetic medium could be maintained, while that of natural sea water might vary. Initially, therefore, manufactured sea water salts were used (dissolved in de-ionized water) but, as is usually the case with such media, metal impurities are chelated by ethylenediamine tetra-acetic acid (EDTA), which would be expected to influence the result of bioassays with metals. Therefore, Analar reagents were then used to make the sea water from a simple formula used successfully for hydroid culture by Tusov \& Davis (1971), but, instead of adding EDTA to bind metal impurities as they did, the water was passed through a large column of Chelax 100 ion exchange resin to remove metal ions 
(Davey et al. 1970). However, this method proved very time-consuming for the large volumes of water required, so the experiments have been performed with water collected near the Eddystone Rock and membrane filtered $(0.45 \mu \mathrm{m})$ before use. It is of almost 'oceanic quality' with metal levels similar to those given by Riley \& Skirrow (1971) for uncontaminated sea water.

Hydroids normally resorb their hydranths when the physical or chemical environment departs sufficiently from the organism's optima and this response is the same whether the cause is suboptimal temperature, salinity or food levels (Tardent, 1963). Furthermore, Karbe (1972) has shown that the stages through which hydranths pass as they regress match exactly the natural degeneration of hydranths (Kinne, 1965). At first, new hydranths cease to be formed, colonial growth rate slows, then stops and the colony shrinks. Colonial growth rate (rate of increase in numbers of hydranths, buds and gonozooids) was chosen as a practical and objective measure of colonial response which would reflect the extent to which the organism is stressed. The growth rate of stolons and longevity of hydranths were also measured, but were less sensitive and more time-consuming to use than colonial growth rate. However, a much more sensitive measure of hydroid response has been developed using a quantitative cytochemical technique (Moore \& Stebbing, 1976). The lowest concentrations of a metal to which different indices of hydroid response are sensitive span four orders of magnitude, which demonstrates that the choice of response can be as important as the choice of organism in achieving sensitivity.

\section{Treatment of data}

The normal growth rate of Campanularia colonies is exponential and the natural logarithm of the number of colony members is linear when plotted against time (Fig. 1 A). The mean relative growth rate (Radford, 1967) is defined as

$$
K=\frac{\log _{e}\left(n_{y}\right)-\log _{e}\left(n_{x}\right)}{t_{y}-t_{x}} .
$$

In this work $n_{x}$ is the number of colony members on the first day $\left(t_{x}\right)$ and $n_{y}$ the number after $y-x$ days $\left(t_{v}\right)$. Experiments usually last 11 days and $K$ is calculated for the whole experiment. However, the linear relationship provides a measure of colonial growth rate which is independent of colony size or age. $K$ can therefore be calculated for successive 2- or 3-day periods using counts at suitable intervals, which make it possible to follow the development of the hydroids' response as a function of time. The doubling time (in days) of colony size can also be calculated from $\left(\log _{e} 2\right) / K$.

The data from an experiment with $\mathrm{Cu}^{2+}$ given in Fig. 1 illustrate some features typical of all the experiments. From the standard deviations it can be seen that, when the control colonies become established and the numbers of colony members increase, variability decreases (Fig. $1 \mathrm{~A}$ ). However, growth rates at $20 \mu \mathrm{g} \mathrm{Cu}^{2+} / 1$ are more variable than those of the control colonies, but this is typical at metal levels near the threshold concentration because the response of stressed colonies is more variable. The two curves together illustrate a feature of the relationship between sensitivity and time, that exposure times of a week or more may be necessary for differences in growth rate between control colonies and those at low metal levels to become significant.

Data are presented as concentration-response curves in which the $K$ values for each experimental period are expressed as percentages of $K$ for the control group (Fig. 1B). In this way experiments can be compared easily although the presentation may conceal variations in the growth rates of control groups between experiments; these are checked regularly and control $K$ values for the last six experiments have yielded a mean value of $K=0.222$ (S.D. \pm 0.0245 ). The pattern of hydroid response to metals is consistent in that $K$ at subthreshold metal concentrations is similar to that of the controls, before the effect of the metal at higher concentrations becomes apparent as a fall in $K$ to a level at which no growth occurs. The point at which the departure of the growth rate curve from the $100 \%$ line becomes significant is the threshold of sensitivity.

The standard error (S.E.) of the mean $K$ of each group of colonies at each treatment is calculated and Bartlett's test is applied to determine whether the data are sufficiently homogeneous to calculate a pooled S.E. (Only once, when a new subculturing method was tried, has significant heterogeneity been found.) Multiples of the pooled S.E. can be plotted as parallels below (or above) the $100 \%$ line as a measure of the probability that departures of the concentration-response 
curve from $100 \%$ are due to chance. In this work three times the pooled S.E. $(P=<0.001)$ is accepted as the level of significance and the intercept of the concentration-response curve with this parallel is the threshold of sensitivity, from which the threshold concentration is derived (Fig. 1B). In this way the threshold concentrations and the sensitivity of the technique are related to the variability of the organisms' response. The concentration-response curves (Fig. 2) include negative values, which represent shrinkage of the colony or negative growth. For simplicity, negative growth is omitted from the concentration-response curves in Figs. 3 and 5 in which all negative values are considered to equal zero.
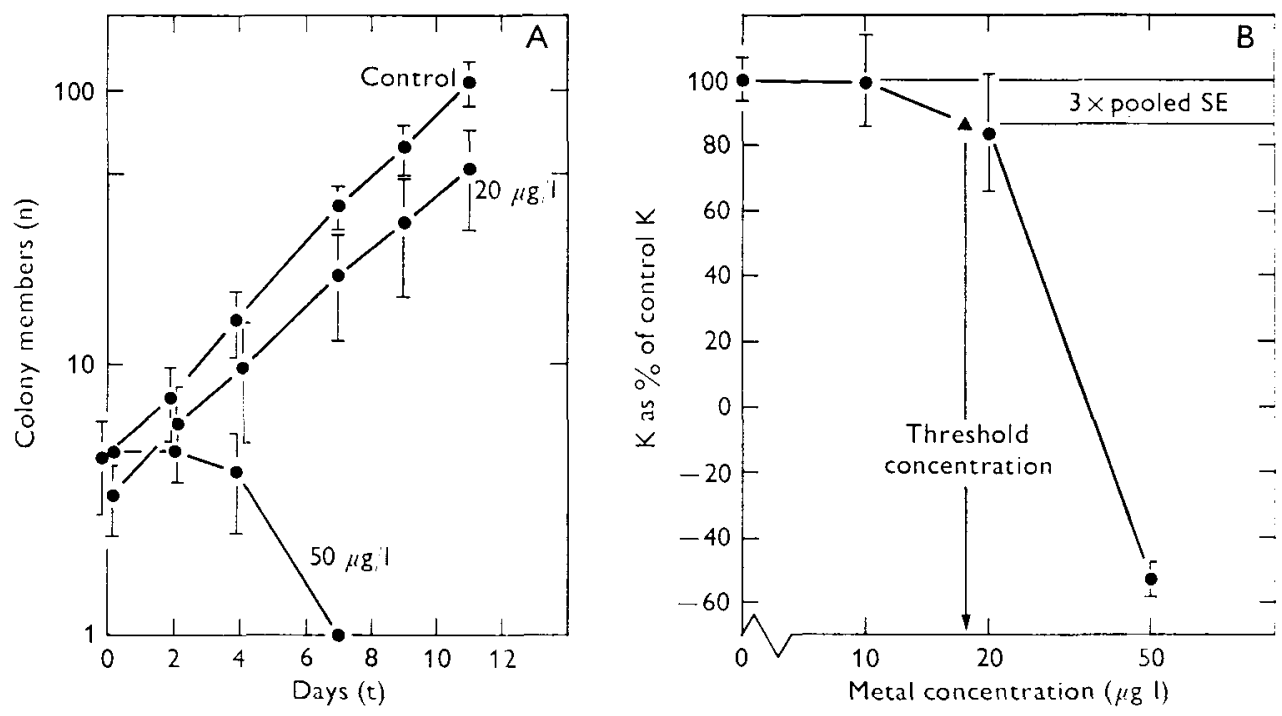

Fig. 1. An illustrative set of data showing the effect of a metal on the colonial growth rate of Campanularia flexuosa. The results are presented in two ways to show the relationship from which $K$ is calculated (A) and the concentration-response curve from which threshold concentrations of metals are determined (B). The data in both figures are from an experiment with $\mathrm{Cu}^{2+}$. In (A) the normal pattern of growth is seen to be linear and $K$ is the slope of this line. In (B) the $K$ values are plotted as a percentage of $K$ for the control colonies. A horizontal line is drawn beneath and parallel to the $100 \%$ line, so that the distance between them is equal to three times the pooled S.E. A perpendicular from the intercept of the concentration-response curve with this line gives the threshold concentration. The standard deviations from the seven replicate colonies at each concentration are plotted for each point on both figures, but the curve for the colonies kept in $10 \mu \mathrm{g} / 1$ and some standard deviation bars are omitted from (A) for clarity.

\section{Experimental solutions}

All experimental solutions are changed daily after feeding. This procedure was prompted by Corner \& Rigler's (1957) work which demonstrated that micro-organisms can remove mercury (added as mercuric chloride) from dilute sea-water solution and coat it on the walls of the vessel. As much as $20 \%$ was lost from solution in 2 days and $80 \%$ in 6 days. Recently their results have been confirmed and extended by Baier, Wojnowich \& Petrie (1975). Although there is no evidence from the literature that this happens with other metals, the practice of changing solutions daily was adopted as a precaution. Many organisms secrete organic compounds (Wagner, 1969), some of which can complex metal ions, and bacteria seem to exude organics in response to elevated metal levels (Jones, 1970). Although the amount of hydroid tissue is small in relation to the volume of water in which the colonies are maintained, any influence of organic secretions on metal toxicity is minimized by daily changes of water. The dilutions of metals in sea water were prepared from standard solutions of the metal chlorides $(1 \mathrm{mg}$ of metal per $\mathrm{ml}$ in $\mathrm{N}$ hydrochloric acid). Occasional analyses after dilution were made to check the accuracy of the nominal concentrations. 


\section{RESULTS}

Concentration-response curves for entire experiments

Concentration-response curves for the effects of $\mathrm{Hg}^{2+}, \mathrm{Cu}^{2+}$ and $\mathrm{Cd}^{2+}$ derived from calculations of $K$ for 11-day experiments are given in Fig. 2, and threshold concentrations determined from them are given in Table 1. The pattern of response is consistent and repeated experiments yield similar curves for the same range of concentrations

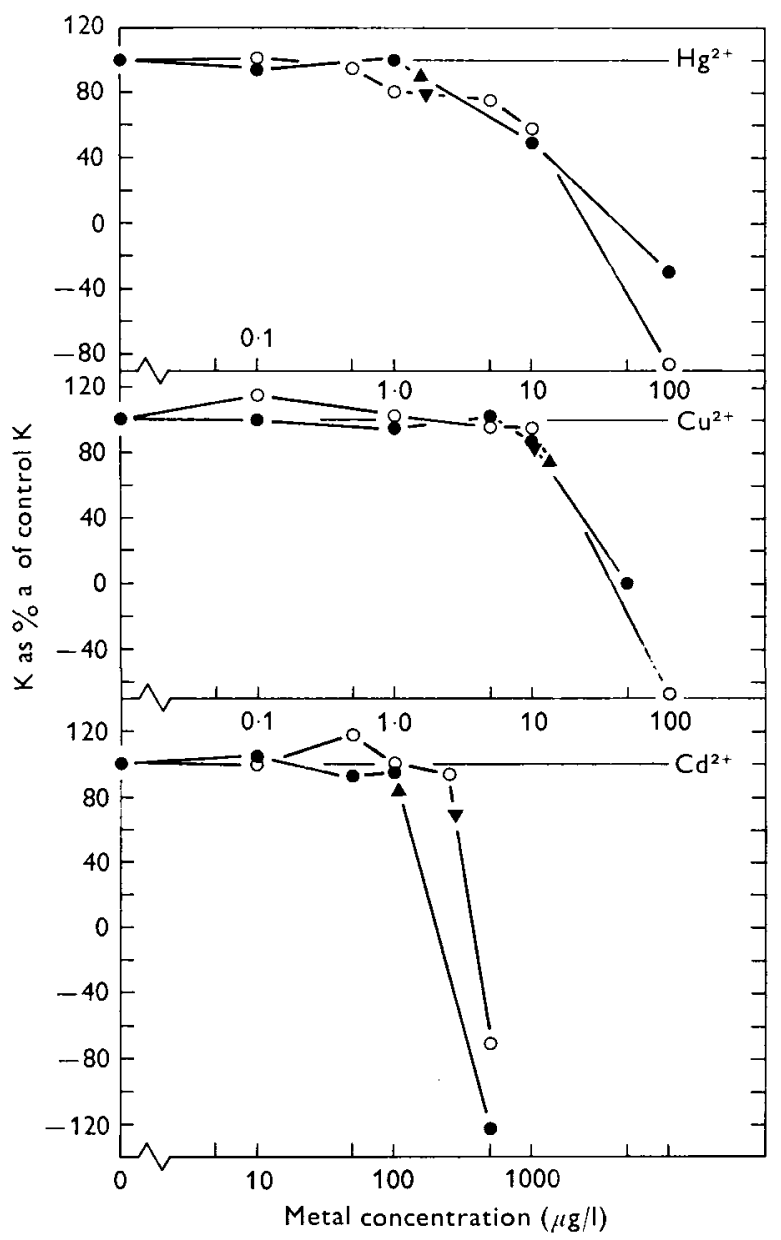

Fig. 2. Concentration-response curves for the effects of $\mathrm{Hg}^{2+}, \mathrm{Cu}^{2+}$ and $\mathrm{Cd}^{2+}$ on hydroid growth rate. In each case curves from two experiments are given: the results from the first are shown as closed circles and the second as open circles. Thresholds of sensitivity are marked as triangles.

(Fig. 2). Usually extra concentrations in the range where the curve falls away from the $100 \%$ line help define the threshold more clearly. Differences between the curves for the experiments with cadmium (Fig. 2) occur chiefly because of the choice of concentrations. In the second experiment the addition of an intermediate concentration 
$\left(250 \mu \mathrm{g} \mathrm{Cd}^{2+} / 1\right)$, which had no effect, resulted in a shift of the curve to the right and this is probably the more accurate result.

Early in this work a clone was lost accidentally, because of the toxic effects of volatile solvents from fibre glass resin used in an adjacent laboratory. In the first experiment with $\mathrm{Hg}^{2+}$ (Fig. 2) the original clone was still in use, although, for all the other experiments described in this paper, the second one was used. The first clone grew consistently faster than the second; values of $K$ for the control colonies in the two experiments with $\mathrm{Hg}^{2+}$ were 0.348 and 0.218 respectively. It is interesting that the concentrationresponse curves are so similar, in spite of the different relative growth rates, implying that the effect of a particular metal concentration is to inhibit the relative growth rate by the same proportion that is independent of the specific relative growth rate of the clone.

TABLE 1. THRESHOLD CONCENTRATIONS, DERIVED FROM CURVES IN FIGURE 2, SHOWING THE LEVELS AT WHICH THE THREE METALS BEGIN TO INHIBIT HYDROID GROWTH RATES

\begin{tabular}{|c|c|c|c|c|c|}
\hline \multicolumn{6}{|c|}{$\begin{array}{l}\text { Metal levels in Eddystone water indicate the background } \\
\text { concentrations in these experiments }\end{array}$} \\
\hline & $\begin{array}{l}\text { Threshold } \\
\text { of } \\
\text { sensitivity } \\
(\mu \mathrm{g} / 1)\end{array}$ & $\begin{array}{l}\text { Levels in } \\
\text { Eddystone } \\
\text { water } \\
(\mu \mathrm{g} / \mathrm{l})\end{array}$ & & $\begin{array}{l}\text { Levels in } \\
\text { ristol Chann } \\
\text { water } \\
(\mu \mathrm{g} / 1)\end{array}$ & \\
\hline $\mathrm{Hg}^{2+}$ & $\left.\begin{array}{l}1 \cdot 7 \\
1.6\end{array}\right\}$ & 0.021 & Gardner, 1975 & $0.01-0.05$ & Gardner \& Riley, 1973a \\
\hline $\mathrm{Cu}^{2+}$ & $\begin{array}{l}13\} \\
10\}\end{array}$ & $0.2-0.5$ & Dr A. W. Morris, pers. comm. & $0.71-5.45$ & Abdullah \& Royle, 1974 \\
\hline $\mathrm{Cd}^{2+}$ & $\left.\begin{array}{l}110 \\
280\end{array}\right\}$ & 0.1 & Dr A. W. Morris, pers. comm. & $1 \cdot 38-4 \cdot 29$ & Abdullah \& Royle, 1974 \\
\hline
\end{tabular}

Mercury was the most toxic metal chloride of those tested, followed by copper and then cadmium - the threshold concentrations increased by about tenfold for each pair of the series. The relative toxicities of the metals are discussed below and compared with results of work elsewhere.

\section{The pattern of response with time}

The effect of the metals on hydroid growth rate was examined as a function of time in order to observe the development of the response with different metals. Furthermore, it was important to determine whether experiments could be shorter than 11 days without loss of sensitivity, or if greater sensitivity might be achieved with longer experiments.

The colony members were counted at intervals during experiments, as well as at the beginning and at the end. Calculations of $K$ were then made for successive 2-, 3- or 4 -day periods. Each experiment can be represented as a family of curves, showing the development of the response with time. In Fig. 3 concentration-response curves are given for an experiment with cadmium. There was no significant response to $500 \mu \mathrm{g}$ $\mathrm{Cd}^{2+} / 1$ as cadmium chloride during the first 4 days, although after 7 days at this 


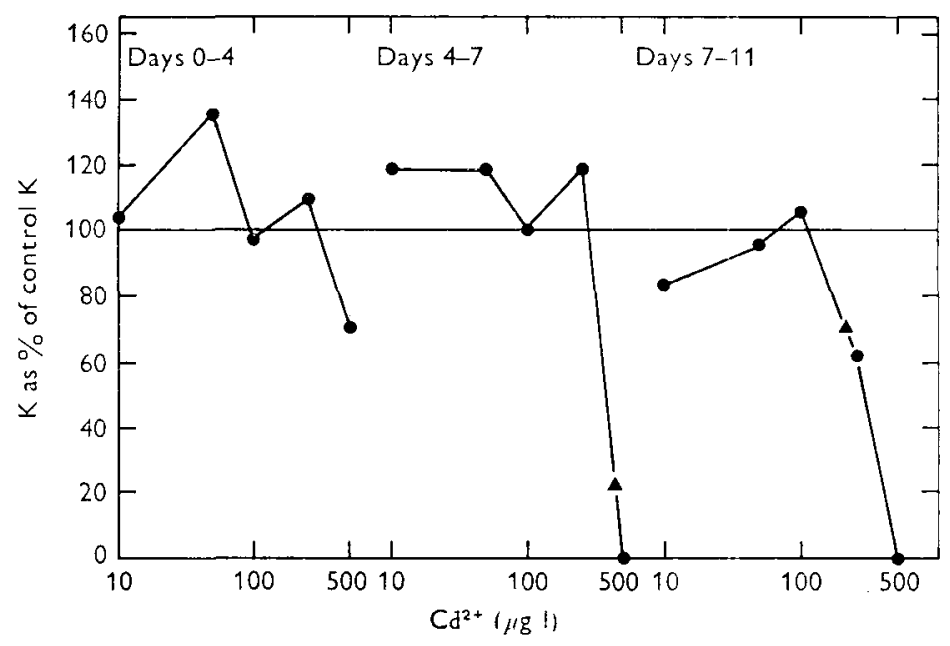

Fig. 3. Concentration-response curves showing the effect of $\mathrm{Cd}^{2+}$ on hydroid growth rate during successive periods of a single experiment. $\boldsymbol{\Delta}$, Thresholds of sensitivity.
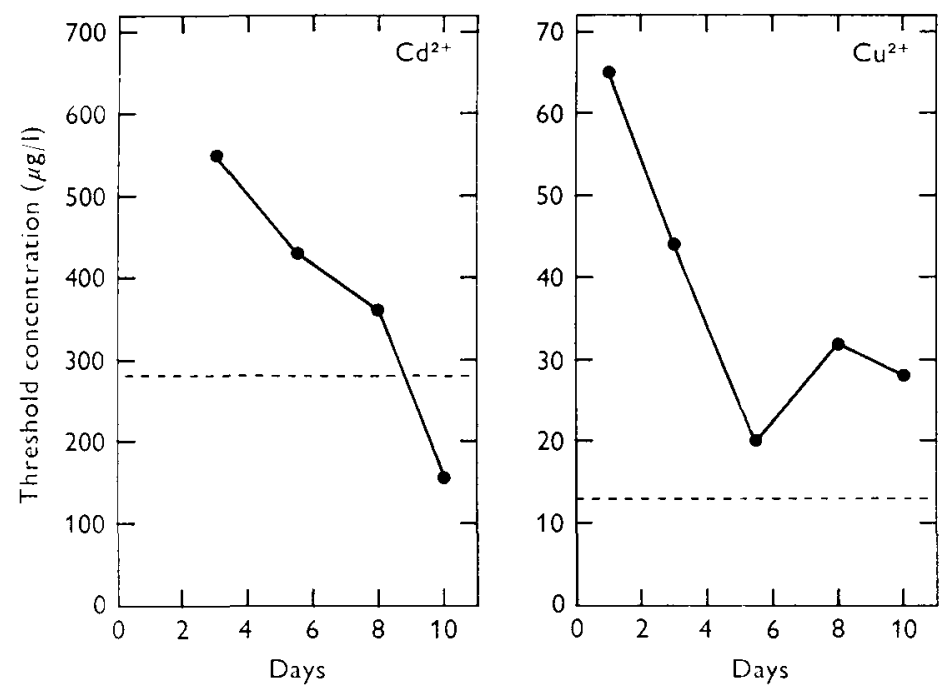

Fig. 4. The relationship between the duration of exposure to $\mathrm{Cd}^{2+}$ and $\mathrm{Cu}^{2+}$ and the threshold concentrations derived from concentration-response curves for successive 2- or 3-day periods during the 11-day experiments. Threshold concentrations from curves for entire experiments are shown as dashed horizontal lines.

concentration the growth rate had fallen to zero and the colonies had died by day 11 . In Fig. 4 the threshold values determined from such curves are plotted as a function of time, showing a linear relationship between sensitivity and the period of exposure. It is notable that the threshold concentration derived from a concentration-response curve for days $9-11$ is about half that derived from a curve for days $0-11$. This is attributable largely to a reduction of the pooled s.E. of $K$ with time and is clearly 
seen in Fig. 5A as a convergence of a line linking thresholds of sensitivity (A) with the $100 \%$ line as the experiment proceeds.

Growth of colonies is always more variable in the early stage of experiments than subsequently; the attachment of all explants is not equally rapid because of variations in the condition of the small number of colony members borne by single uprights. Consequently, when interpreting Figs. 3 and 5 less weight should be attached to variations early in experiments and more to those at the end.
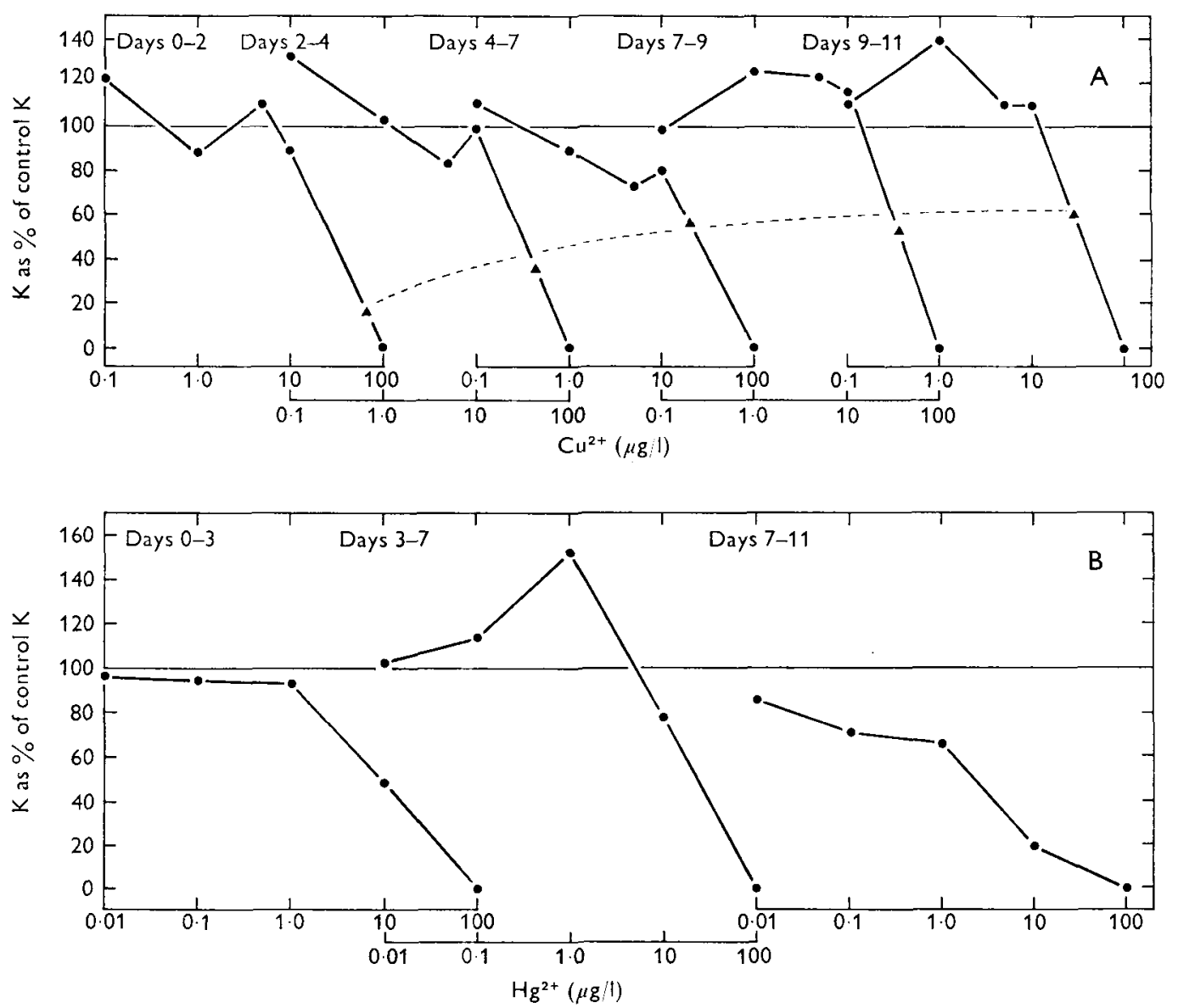

Fig. 5. Concentration-response curves showing the effects of $\mathrm{Cu}^{2+}(\mathrm{A})$ and $\mathrm{Hg}^{2+}(\mathrm{B})$ on hydroid growth rate during successive periods of single experiments. Thresholds of sensitivity for $\mathrm{Cu}^{2+}$ are marked with triangles $(\boldsymbol{A})$, which are linked with a dashed line to show that the pooled S.E. decreases, and therefore converges with the $100 \%$ line as the experiment proceeds.

The results imply, in the case of cadmium (Fig. 4) that longer exposure might result in lower threshold values. Copper and mercury differ in that they take effect more quickly and the lowest threshold values are reached after 4-7 days, but here the stimulatory effects of subthreshold metal levels (see below) confuse the relationship between sensitivity and duration of exposure. 


\section{The stimulatory effect of subthreshold metal concentrations}

A series of concentration-response curves for copper (Fig. 5A), similar to that for cadmium (Fig. 3), shows that the development of the hydroids' response with time is quicker for copper than cadmium. More interesting is the fact that after 7 days, the growth rate at $1 \mu \mathrm{g} \mathrm{Cu}^{2+} / 1$ is stimulated to an extent that becomes significant in the last two days of the experiment. This stimulatory effect of copper has been demonstrated in repeated experiments, although stimulation may not always persist until the end of the experiment, as is the case in Fig. 5A. The relationship between the length of exposure to copper and threshold concentrations from concentration-response curves for 2- or 3-day intervals (Fig. 4) shows a steep decline at first, followed by a peak when growth is stimulated. It would be of interest to determine the point at which the curve becomes asymptotic, but experiments have so far been limited to 11 days by the dimensions of the plates on which they are grown.

Mercury (Fig. 5A) also stimulates growth rate; but it is a transitory effect, occurring only between days 3 and 7 . Growth at $1 \mu \mathrm{g} \mathrm{Hg}^{2+} / 1$ during this period is stimulated to a level of $35 \%$ above that of the control colonies, falling by $70 \%$ during the last 4 days of the experiment.

\section{DISCUSSION}

\section{Relative sensitivity with other bioassays}

One object in this attempt to develop a sensitive bioassay technique has been to produce a method for studying contaminants at levels similar to those found in polluted waters, so that we can determine the lowest concentrations at which the effect of toxic substances becomes detectable. The data presented here show that the hydroid bioassay is as sensitive to the metals tested as any methods in current use. The more sensitive kinds of bioassay and the lowest levels of mercuric chloride to which they respond are summarized in Table 2 for comparison with the highest levels of dissolved mercury that have been found in the field (Table 3). The juxtaposition of the two sets of data (Fig. 6) implies that only the most sensitive bioassays would be expected to respond to the highest dissolved mercury levels reported and, therefore, that only these techniques would be useful in assessing field data. However, caution should be used in extrapolating the results of laboratory experiments with mercuric chloride to the field, because the forms of mercury in natural waters (Fagerström \& Jernelöv, 1972) and their toxicity (Corner \& Sparrow, 1957) vary significantly. Hydroids were first employed for the bioassay of marine contaminants by Karbe (1972), who found that the appearance of abnormalities in cultured colonies of Eirene viridula provided the most sensitive index of their response to metals. The relative sensitivities of Karbe's method and that using Campanularia are being compared in intercalibration experiments. Significant improvements in the sensitivity of the technique can be achieved by deriving threshold values from concentration-response curves for the last 2 or 4 days of an experiment, since a response may not become apparent at the lower concentrations until colonies have been exposed to the metal for a week (p. 983). For example, a concentration-response curve for the effect of $\mathrm{Hg}^{2+}$ as mercuric chloride over 11 days (Fig. 2) gives a threshold 
concentration of $1.6 \mu \mathrm{g} \mathrm{Hg}^{2+} / 1$, but a curve for days 7-11 from the same experiment (Fig. 5B) gives a threshold concentration of $0.46 \mu \mathrm{g} / 1$. Similarly, threshold concentrations for cadmium chloride derived from $K$ values for complete 11 day experiments (Fig. 2; Table 1) are twice those derived from $K$ for the last 2 days of the same experiments (Fig. 4).

\section{TABLE 2. THRESHOLDS OF SENSITIVITY OF BIOASSAYS TO MERCURIC CHLORIDE}

A range of bioassay results is given including particularly those that are most sensitive. The numbers 1-27 refer to those beside each point in Fig. 6 . Those threshold values marked with an asterisk indicate approximate values determined by me from data given by the authors. Threshold

No. $\quad(\mu \mathrm{g} / 1)$

Type of bioassay

Organism

Author

\section{ANIMALS - MARINE INVERTEBRATES}

$\begin{array}{lc}1 & 1-3 \\ 2 & 1-3 \cdot 3 \\ 3 & 1 \cdot 8 \\ 4 & 2 \cdot 5 \\ 5 & 4 \cdot 8 \\ 6 & 5 \cdot 6 \\ 7 & 10 \\ 8 & 10 \\ 9 & 10 \\ 10 & 14 \\ 1 & 27 \\ 2 & 33-100 \\ 3 & 50 \\ 4 & 50-64 \\ 5 & 75 \\ 6 & 100 \\ 7 & 140 \\ 8 & 200 \\ 9 & 300 \\ 20 & 1200\end{array}$

Morphological abnormalities

Larval LC 50 (48 h)

Larval metabolism and survival affected

Inhibition of population growth rate

Larval LC 50 (48 h)

Larval LC 50 ( $48 \mathrm{~h}$ )

Larval LC50 (48 h)

Inhibition of growth

Stimulation of respiration rate

Larval LC 50 (48 h)

Larval morphological abnormalities

Larval LC $50(48 \mathrm{~h})$

LC $50(2.5 \mathrm{~h})$

LC $50(96 \mathrm{~h})$

LC $50(48 \mathrm{~h})$

Larval LC50 (2 h)

Larval LC50 $(2 \mathrm{~h})$

Larval LC $50(2 \mathrm{~h})$

Larval LC $50(2.5 \mathrm{~h})$

Larval LC50 (2 h)
Eirene viridula

Ostrea edulis

Uca pugilator

Cristigera sp.

Mercenaria mercenaria

Crassostrea virginica

Crangon vulgaris

L-cells in tissue culture $\mathrm{Li} \&$ Traxler, 1972

Congeria leucophaeata

Carcinus maenas

Crassostrea gigas

Homarus vulgaris

Acartia clausi

Petrolisthes armatus

Pandalus montagui

Watersipora cucullata

Spirorbis lamellosa

Bugula neritina

Elminius modestus

Galeolaria caespitosa
Karbe, 1972

Conner, 1972

De Coursey \& Vernberg, 1972

Gray \& Ventilla, 1973

Calabrese \& Nelson, 1974

Calabrese et al. 1973

Connor, 1972

Dorn, 1974

Connor, 1972

Woelke, 1965

Connor, 1972

Corner \& Sparrow, 1956

Roesijadi et al. 1974

Portmann, 1968

Wisely \& Blick, 1967

Wisely \& Blick, 1967

Wisely \& Blick, 1967

Corner \& Sparrow, 1956

Wisely \& Blick, 1967

\section{PLANTS - UNICELIULAR ALGAE (INCLUDING SOME FRESHWATER SPECIES)}

In crease in cell size and inhibition of population growth

Inhibition of population growth

Inhibition of population growth

Inhibition of growth

Inhibition of population growth

Inhibition of growth

$\mathrm{LD}_{5} \mathrm{O}(\mathrm{O} .5 \mathrm{~h})$ of sporelings
Isochrysis galbana

Davies, 1974

Chlamydomonas sp.

Chlorella pyrenoidosa

Scenedesmus dimorphus

Chaetoceros costatum,

Cyclotella nana and

Phaeodactylum tricornutum

Chlamydomonas

reinhardi

Plumularia elegans
Nuzzi, 1972

Kamp-Nielsen, 1971

Matida et al. 1971

Hannan \& Patouillet, 1972

Ben-Bassat et al. 1972

Boney \& Corner, 1959

\section{Relative toxicity of metals}

Prediction of the effects of metals depends partly upon the validity of the generalizations that may be made about their toxicity. Irving \& Williams (1953) demonstrated that the stability of complexes formed by bivalent ions of the first transition series follows the order $\mathrm{Mn}<\mathrm{Fe}<\mathrm{Co}<\mathrm{Ni}<\mathrm{Cu}<\mathrm{Zn}$, irrespective of the nature of the ligand. Shaw (1961) postulated that, since metals are toxic to organisms because they combine with active groups necessary for life as, for example, $-\mathrm{SH}$ groups on enzymes, 
the toxicity of these metals might follow the Irving-Williams order. Shaw (1954) and others found, using enzymes and a range of organisms from protozoa to fish, that the toxicity of metals always follows this sequence.

\section{TABLE 3. RECENT LEVELS OF DISSOLVED MERCURY IN SEA-WATER SAMPLES}

The left-hand column of numbers refer to points in Fig. 6.

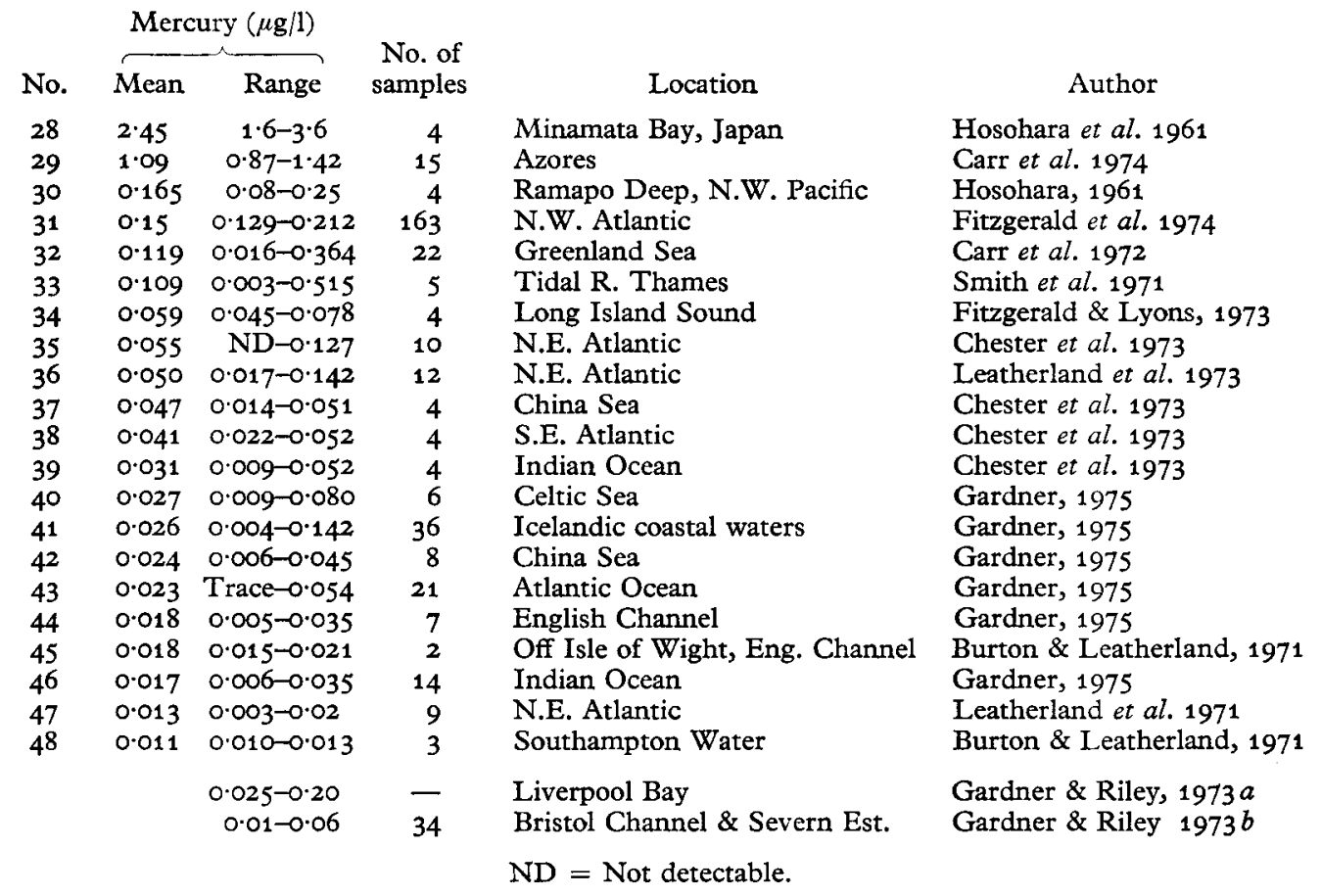

Jones, in his studies with Gasterosteus (1939) and Polycelis (1940) appears to have initiated the search for physicochemical characteristics of metals that correlate with their toxic effects upon aquatic organisms. He found that toxicity increased with the standard electrode potential ('solution pressure') of the metal. Danielli \& Davies (1951) considered that electrode potentials could not be expected to give any numerical correlation for theoretical reasons and that the closer relationship between electronegativity and toxicity (using Jones's data) reflected their view that metal ions exert an effect by interaction with the cell surface. More recently Biesinger \& Christensen (1972) using Daphnia magna have also demonstrated a linear correlation between the toxicity of metals and their electronegativity. Corner \& Sparrow (1957) and Corner \& Rigler (1958) studied the effects of a range of organo-mercury compounds upon Elminius modestus larvae and Artemia salina. They found that the effects were not related to their absolute toxicity, as demonstrated by their ability to inhibit urease activity, but to their ability to penetrate the organism, lending support to Danielli \& Davies' ideas. Corner and his co-workers found a close correlation between the toxicity of the organomercurials and their lipid solubility, and it is now generally accepted that 
lipid soluble substances pass through membranes more easily, since membranes typically contain about $40 \%$ lipid.

Whatever physicochemical correlates seem most significant, where others have determined the toxicity to aquatic species of the same metals as those used in this study, the sequence of descending toxicity has been the same: $\mathrm{Hg}>\mathrm{Cu}>\mathrm{Cd}$ (Shaw \& Lowrance, 1956; Brown \& Ahsanullah, 1971; Kobayashi, 1971; Karbe, 1972; Biesinger \& Christensen, 1972; Calabrese et al. 1973).

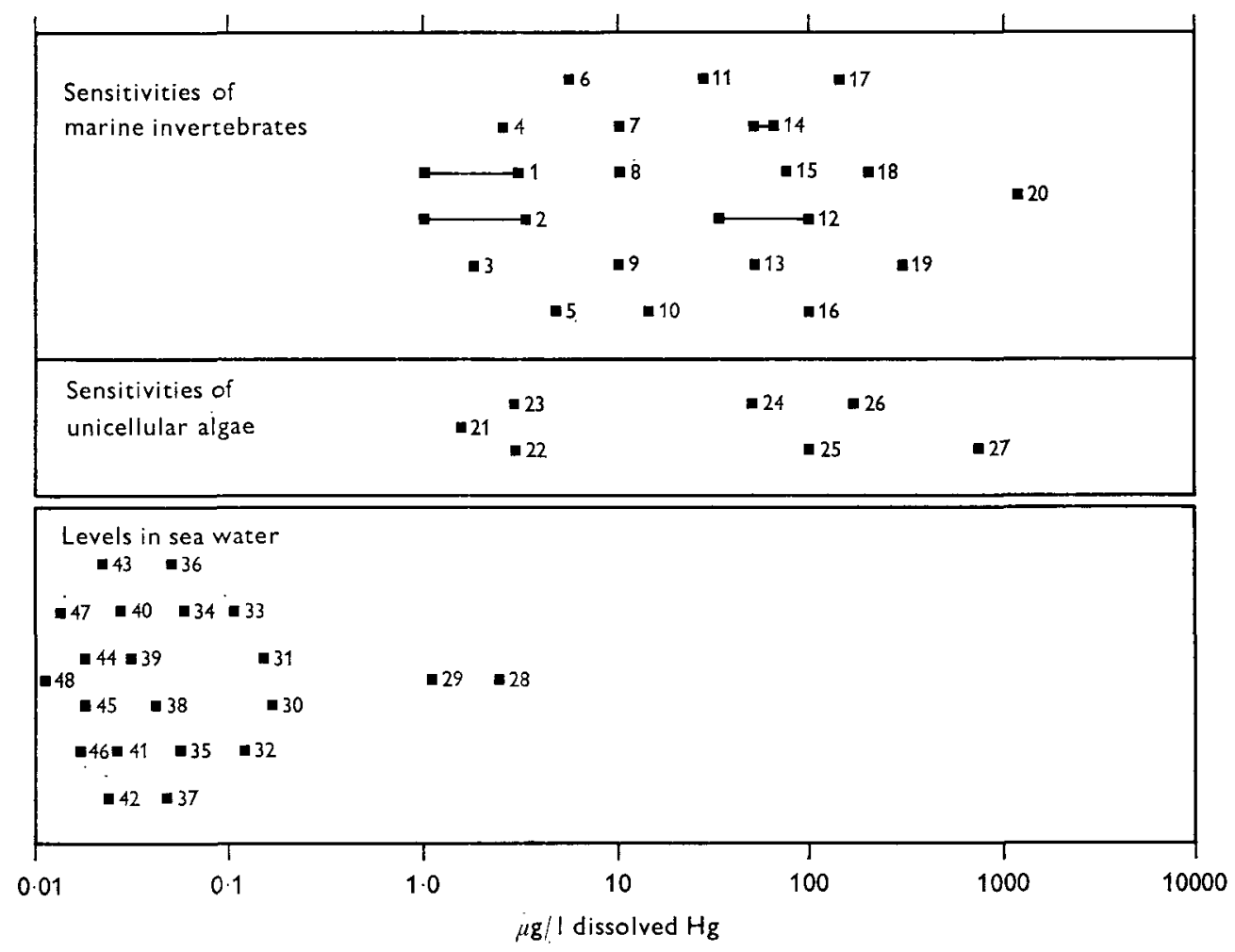

Fig. 6. The maximum sensitivities of bioassay techniques to mercuric chloride plotted beside the levels of total dissolved mercury found in sea-water samples. The number beside each point refers to data listed in Tables 2 or 3 .

During this work a number of differences between the toxic effects of cadmium and the other two metals have become apparent which suggests that cadmium may act in a different manner. The range of concentrations from the no-effect level to that which is lethal is very narrow and is almost an 'all-or-nothing' response, while the changing effects of copper and mercury are more gradual as metal concentrations increase (Fig. 2). Cadmium also differs in that it seems to act more slowly than copper or mercury and there is no significant response in the first 4 days of exposure to concentrations that later prove lethal (Fig. 3).

Cadmium is also unusual in that its toxicity changes from fresh to salt water. A change such as this is difficult to study because sub-optimal salinity acts as a stressor in its 
own right, enhancing the effect of another stressor - such as a toxic metal. Here though we are considering the exogenous interactions of cadmium with the constituents of the water and the consequent changes in the toxic properties of the cadmium complex. In a series of papers on the effect of cadmium on the development of eggs of herring, garpike and flounder (Westernhagen, Rosenthal \& Sperling, 1974; Westernhagen \& Dethlefsen, 1975; Westernhagen, Dethlefsen \& Rosenthal, 1975) it has been shown that there is a decline in the toxic effects of cadmium with increasing salinity. In a review of the literature of the effects of cadmium covering over 60 examples using different organisms or by different authors, the modal concentrations for the sensitivity of fresh water species was found to be an order of magnitude lower than those for marine species. Westernhagen and his co-workers support a theory that the toxicity of cadmium is reduced by its interactions with calcium. The correlation with salinity is thought to result from the greater abundance of calcium in sea water than fresh water. Although the mechanism is hypothetical, there seems little doubt of the significance of the change in toxicity.

\section{The pattern of response with time}

It has long been known that there is a relationship between the effect of toxic levels of substances and the period over which they are absorbed by an organism, which implies that a large amount taken in over a short period will have a similar effect to small amounts over a long period. This was first known as Haber's Rule for equitoxic doses (Haber, 1924) and is expressed in the form $c t=K$ relating the concentration of a substance $(c)$ and the period over which it is absorbed $(t)$ to a constant $(K)$. Herbert (1952) found that this kind of relationship also applied to the effects of most toxic substances on fish. However, the extremities of these relationships lead one to the improbable conclusion that a high enough concentration will have an instantaneous effect and an infinite dilution will have an effect in infinite time. In environmental toxicology the problem is whether very low concentrations have an effect on biological processes exposed continuously to those levels. Haber's Rule and Herbert's more recent statement of it have led to conclusions such as Hynes's (1971) that for most metals there is no theoretical concentration which will not ultimately cause death. However, it is well known that many metals toxic at high concentrations are essential for life at lower levels and organisms may have mechanisms to break down, sequester, excrete or otherwise inactivate toxic substances. Hayes's (1975) restatement of Haber's Rule recognizes that such mechanisms exist, so that a 'sufficiently high rate of detoxification would negate prolonged exposure to a sufficiently low concentration'.

Little is known about detoxification mechanisms in aquatic organisms and mechanisms, such as those involving metallothionein in mammals, must be identified before they can be quantified. Until then, attempts to understand the relationships between concentration and duration of exposure to the very low levels found in sea water must be empirical. Our results with cadmium show a linear decline in threshold concentration with time (Fig. 4) and, if the experiment could have been longer, the curve would probably have become asymptotic. 


\section{The stimulatory effects of subthreshold metal levels}

The stimulatory effects of low concentrations of cupric and mercuric chloride on hydroid growth rate have been described (Fig. 5A, B). Similar effects of toxic substances have been known for many years as the Arndt-Schulz Effect (Schulz, 1888). Numerous pharmacological examples have been cited (Townsend \& Luckey, 1960), but, in toxicology, stimulatory effects are often attributed to errors or artifacts because they are unexpected (Smyth, 1967). The effect is well illustrated in man by the temporary stimulatory effects on metabolism of subinhibitory levels of toxins such as caffeine in coffee and nicotine in tobacco. For more than a century arsenic has been used as a general tonic and for the treatment of some diseases in man and animals. More recently it has become widely used as a growth stimulant in the diet of poultry, pigs and cattle (Stare, 1956). In marine organisms a number of examples of the stimulatory effect of metals have been described, but usually no attempt is made to explain them (Table 4).

\section{TABLE 4. RECORDS OF STIMULATORY EFFECTS OF HEAVY METALS}

\begin{tabular}{|c|c|c|}
\hline Metal & Observations & Author \\
\hline Metals & Increase in respiration rate of Gammarus & Jones, 1941 \\
\hline $\mathrm{Hg}$ & $\begin{array}{l}\text { Increase in respiration rate of Arbacia } \\
\text { sperm }\end{array}$ & Barron et al. 1948 \\
\hline $\mathrm{Cu}, \mathrm{Hg}$ & $\begin{array}{l}\text { Increase in respiration and heart rate } \\
\text { Marinogammarus }\end{array}$ & Russell Hunter, 1949 \\
\hline $\mathrm{Cu}, \mathrm{Zn}$ & $\begin{array}{l}\text { Increase in respiration rate of Hemi- } \\
\text { centrotus sperm }\end{array}$ & Mohri, 1956 \\
\hline $\mathrm{Cu}$ & Increase in respiration rate of Nereis & Raymont \& Shields, 1962 \\
\hline $\mathrm{Cu}, \mathrm{Ni}$ & Increase in bacterial growth rate & Jones, 1970 \\
\hline $\mathrm{Hg}$ & $\begin{array}{l}\text { Increase in respiration rate of larval } \\
U_{c a}\end{array}$ & DeCoursey \& Vernberg, 1972 \\
\hline & Increase in respiration rate of Congeria & Dorn, 1974 \\
\hline $\mathrm{Zn}, \mathrm{Hg}, \mathrm{Cu}$ & Increase in swimming rate of urchin sperm & Young \& Nelson, 1974 \\
\hline
\end{tabular}

It is important to differentiate between the Arndt-Schulz Effect and the Law of Optimal Nutritive Concentration (Bertrand, 1962), which established that the relationship between the concentrations of essential trace elements and their physiological functions is diphasic in plants. Since then this has been found to apply generally in biological systems. The Arndt-Schulz Effect differs in that firstly, the availability of micronutrients is optimal when the organism is stimulated by a toxic substance, so the stimulatory effect is not the result of satisfying a deficiency. Secondly, the agents causing stimulation are not necessarily trace micronutrients; and thirdly, the stimulatory effects are usually transitory, as is demonstrated in this paper. It would seem that the temporary stimulatory effects may be one aspect of an animal's normal homeostatic responses to stressors and the apparent absence of these effects in higher plants and microalgae (Steeman Nielsen \& Wium-Anderson, 1970; Davies, 1974) is not surprising, because homeostatic mechanisms are much simpler in plants.

One of the most difficult problems in the study of contamination of aquatic environments is to discover the levels of toxic substances that have no deleterious effects. A 'no-effect' level of a toxin is most difficult to determine, but the Arndt-Schulz Effect 
provides an apparently normal and measurable response to subinhibitory levels of toxins (Smyth, 1967) and may have a useful role to play in operational bioassay methods.

I would like to thank Dr A. W. Morris for his guidance in metal chemistry, Mr P. J. Radford in the treatment of data and Mr N. R. Cotter, Mr A. J. Pomroy and Mrs L. Killer for technical assistance. I am most grateful to the Director and staff of the Marine Biological Association for providing workshop and photographic facilities. This work forms part of the experimental ecology programme of the Institute for Marine Environmental Research, a component of the Natural Environment Research Council. It was commissioned in part by the Department of the Environment (contract no. DGR 480/47).

\section{REFERENCES}

Abduliah, M. I. \& Royle, L. G., 1974. A study of the dissolved and particulate trace elements in the Bristol Channel. Fournal of the Marine Biological Association of the United Kingdom, 54, 581-597.

Albert, A., 1968. Selective Toxicity, 4th ed. 531 pp. London: Methuen.

Baier, R. W., Wojnowich, J. \& Petrie, L., 1975. Mercury loss from culture media. Analytical Chemistry, 47, 2464-2467.

Barron, E. S. G., Nelson, L. \& ARDAO, M. I., 1948. Regulatory mechanisms of cellular respiration. II. The role of soluble sulfhydryl groups as shown by the effect of sulfhydryl reagents on the respiration of sea urchin sperm. Fournal of General Physiology, 32, 179-190.

Ben-bassat, D., Shelef, G., Gruner, N. \& Shuval, H. I., 1972. Growth of Chlamydomonas in a medium containing mercury. Nature, London, 240, $43-44$.

BERTRAND, D., 1962. Sur une formule mathématique de la loi de l'optimum de concentration nutritive. Compte rendu hebdomadaire des séances de l'Académie d'agriculture de France, 254, $2810-2812$.

BIEsinger, K. E. \& Christensen, G. M., 1972. Effects of various metals on survival, growth, reproduction and metabolism of Daphnia magna. fournal of the Fisheries Research Board of Canada, 29, 1691-1700.

BoneY, A. D. \& CoRNER, E. D. S., 1959. Application of toxic agents in the study of the ecological resistance of intertidal red algae. Fournal of the Marine Biological Association of the United Kingdom, 38, 267-275.

Braverman, M., 1974. The cellular basis of morphogenesis and morphostasis in hydroids. Oceanography and Marine Biology, an Annual Review, 12, 129-221.

Brown, B. \& Ahsanullah, M., 1971. Effect of heavy metals on mortality and growth. Marine Pollution Bulletin, 2, 182-187.

Burton, J. D. \& LeAtHerLAND, T. M., 1971. Mercury in a coastal marine environment. Nature, London, 231, 440-444.

Calabrese, A., Collier, R. S., Nelson, D. A. \& Macinnes, J. R., 1973. The toxicity of heavy metals to embryos of the American oyster Crassostrea virginica. Marine Biology, 18, 162166.

Calabrese, A. \& Nelson, D. A., 1974. Inhibition of embryonic development of the hard clam, Mercenaria mercenaria, by heavy metals. Bulletin of Environmental Contamination and Toxicology, 11, 92-97.

CARR, R. A., Hoover, J. B. \& WILKNESS, P. E., 1972. Cold-vapor atomic absorption analysis for mercury in the Greenland Sea. Deep-Sea Research 19, 747-752.

CARR, R. A., Jones, M. M. \& Russ, E. R., 1974. Anomalous mercury in near-bottom water of a mid-Atlantic rift valley. Nature, London, 251, 489-490.

Chester, R., Gardner, D., Riley, J.P. \& Stoner, J., 1973. Mercury in some surface waters of the world ocean. Marine Pollution Bulletin, 4, 28-20.

ConNor, P. M., 1972. Acute toxicity of heavy metals to some marine larvae. Marine Pollution Bulletin, 3, 190-192. 
CoRner, E. D. S. \& RIGLER, F. H., 1957. The loss of mercury from stored sea-water solutions of mercuric chloride. Fournal of the Marine Biological Association of the United Kingdom, 36, 449-458.

CoRNER, E. D.S. \& RIGLeR, F. H., 1958. The modes of action of toxic agents. III. Mercuric chloride and $N$-amylmercuric chloride on crustaceans. Fournal of the Marine Biological Association of the United Kingdom, 37, 85-96.

CoRnER, E. D. S. \& SPARROW, B. W., 1956. The modes of action of toxic agents. I. Observations on the poisoning of certain crustaceans by copper and mercury. Fournal of the Marine Biological Association of the United Kingdom, 35, 531-548.

Corner, E. D. S. \& SPARrow, B. W., 1957. The modes of action of toxic agents. II. Factors influencing the toxicities of mercury compounds to certain crustaceans. Fournal of the Marine Biological Association of the United Kingdom, 36, 459-472.

Crowell, S., 1957. Differential responses of growth zones to nutritive level, age and temperature in the colonial hydroid Campanularia. Fournal of American Zoology, 134, 63-90.

DANIELLI, J. F. \& DAvies, J. T., 1951. Reactions at interfaces in relation to biological problems. Advances in Enzymology, 11, 35-89.

Davey, E. W., Gentile, J. H., ERICKson, S. J. \& Betzer, P., 1970. Removal of trace metals from marine culture media. Limnology and Oceanography, 15, 486-488.

Davies, A. G., 1974. The growth kinetics of Isochrysis galbana in cultures containing sublethal concentrations of mercuric chloride. Fournal of the Marine Biological Association of the United Kingdom, 54, 157-169.

De Coursey, P. J. \& Vernberg, W. B., 1972. Effect of mercury on survival, metabolism and behaviour of larval Uca pugilator (Brachyura). Oikos, 23, 241-247.

DoRn, P., 1974. The effects of mercuric chloride upon respiration in Congeria leucophaeata. Bulletin of Environmental Contamination and Toxicology, 12, 86-91.

FAgerström, T. \& JeRnELöv, A., 1972. Some aspects of the quantitative ecology of mercury. Water Research, 6, 1193-1202.

FitzGerald, R. A., Gordon, D. C. \& Cranston, R. E., 1974. Total mercury in sea water in the northwest Atlantic Ocean. Deep-Sea Research, 21, 139-144.

FItZGERAID, W. F. \& LyoNs, W. B., 1973. Organic mercury compounds in coastal waters. Nature, London, 242, 452-453.

Fulton, C., 1962. Environmental factors influencing the growth of Cordylophora. fournal of Experimental Zoology, 151, 61-78.

GARDNER, D., 1975. Observations on the distribution of dissolved mercury in the ocean. Marine Pollution Bulletin, 6, 43-46.

Gardner, D. \& RILEY, J. P., 1973 $a$. The distribution of dissolved mercury in the Bristol Channel and Severn Estuary. Estuary and Coastal Marine Science, 1, 191-192.

GARDNER, D. \& RileY, J. P., 1973 $b$. Distribution of dissolved mercury in the Irish Sea. Nature, London, 241, 526-527.

Gray, J. S. \& VentILIA, R. J., 1973. Growth rates of a sediment-living marine protozoan as a toxicity indicator for heavy metals. Ambio, 11, 118-121.

HABER, F., 1924. Zur Geschichte des Gaskrieges. In Fünf Vorträge aus den fahren 1920-1923, pp. 76-92. Berlin: Julius Springer.

Hannan, P. J. \& Patourilet, C., 1972. Effect of mercury on algal growth rates. Biotechnology and Bioengineering, 14, 93-101.

Harriss, R. C., White, D. B. \& Macfarlane, R. B., 1970. Mercury compounds reduce photosynthesis by plankton. Science, New York, 170, 736-737.

HaUENSCHILD, C., 1954. Genetische und entwicklungsphysiologische Untersuchungen über Intersexualität und Gewebeverträglichkeit bei Hydractinia echinata Flemm. (Hydroz. Bougainvill.). Roux Archiv für Entwicklungsmechanik der Organismen, 147, 1-41.

Hayes, W. J., 1975. Toxicology of Pesticides. 580 pp. Baltimore: Williams and Wilkins.

Herbert, D. W. M., 1952. Measurement of the toxicity of substances to fish. Fournal of the Institute for Sewage Purification, 1, 60-68.

Hosohara, K., 1961. Mercury content of deep-sea water. Fournal of the Chemical Society of fapan, 82, 1107-1108. (In Japanese.)

Hosohara, K., Kozuma, H., Kawasaki, K. \& Tsuruta, T., 1961. Studies on the total amount of mercury in sea water. Fournal of the Chemical Society of fapan, 82, 1479-1480. (In Japanese.) 
HyNEs, H. B. N., 1971. The Biology of Polluted Water. 202 pp. Liverpool: Liverpool University Press.

IRVING, H. \& WILLIAMS, R. J. P., 1953. The stability of transition-metal complexes. fournal of the Chemical Society, pp. 3192-3120.

JoNEs, G. E., 1964. Effect of chelating agents on the growth of Escherichia coli in sea water. fournal of Bacteriology, 87, 483-499.

JoNES, G. E., 1970. Metal organic complexes formed by marine bacteria. In Organic Matter in Natural Waters. Proceedings of a Symposium, Alaska, 1968 (ed. D. W. Hood), pp. 301-319. Alaska: University of Alaska Press.

JoNES, J. R. E., 1939. The relation between the electrolytic solution pressures of the metals and their toxicity to the stickleback (Gasterosteus aculeatus). Fournal of Experimental Biology, 16, 425-437.

JoNES, J. R. E., 1940. A further study of the relation between toxicity and solution pressure, with Polycelis nigra as test animal. Fournal of Experimental Biology, 17, 408-415.

JoNEs, J. R. E., 1941. The effects of ionic copper on the oxygen consumption of Gammarus pulex and Polycelis nigra. Fournal of Experimental Biology, 18, 153-161.

KAMP-NIELSEN, L., 1971. The effect of deleterious concentrations of mercury on the photosynthesis and growth of Chlorella pyrenoidesa. Physiologia plantarum, 24, 556-561.

KARBE, L., 1972. Marine Hydroiden als Testorganismen zur Prüfung der Toxizität von Abwasserstoffen. Die Wirkung von Schwermetallen auf Kolonien von Eirene viridula. Marine Biology, $12,316-328$.

KINNE, O., 1965. Über den Einfluss des Salzgehaltes und der Temperatur auf Wachstum, Form und Vermchrung bei dem Hydroidpolypen Cordylophora caspia (Pallas), Thecata, Clavidae. Zoologische Jahrbïcher. Abteilung Allgemeine Zoologie und Physiologie der Tiere, 66, 565638.

KobaYASHI, N., 1971. Fertilized sea urchin eggs as an indicatory material for marine pollution bioassay, preliminary experiments. Publications of the Seto Marine Biological Laboratory, 18, 379-406.

Leatherland, T. M., Burton, J. D., Culkin, F., McCartney, M. J. \& Morris, R. J., 1973. Concentrations of some trace metals in pelagic organisms and of mercury in north-east Atlantic Ocean. Deep-Sea Research, 20, 679-685.

Leatherland, T. M., Burton, J. D., McCartney, M. J. \& Culkin, F., 1971. Mercury in north-eastern Atlantic Ocean water. Nature, London, 232, 112.

LI, M. F. \& TRAXIER, G. S., 1972. Tissue culture bioassay method for water pollution with special reference to mercuric chloride. Fournal of the Fisheries Research Board of Canada, 29, 501-505.

Matida, Y., Kumada, H., Kimura, S., Saiga, Y., Nose, T., Yokote, M. \& Kawatsu, H., 1971. Toxicity of mercury compounds to aquatic organisms and accumulation of the compounds by the organisms. Bulletin of the Freshwater Fisheries Research Laboratory, 21, 197-227.

MoHRI, H., 1956. Studies on the respiration of sea-urchin spermatozoa. II. The cytochrome oxidase activity in relation to the dilution effect. Fournal of Experimental Biology, 33, $330-337$.

Moore, M. N. \& Stebing, A. R. D., 1976. The quantitative effects of three metal ions on a lysosomal hydrolase of a hydroid. Fournal of the Marine Biological Association of the United Kingdom, 56, 995-1005.

Nuzzr, R., 1972. Toxicity of mercury to phytoplankton. Nature, London, 237, 38-40.

PortmanN, J.E., 1968. Progress report on a programme of insecticide analysis and toxicity testing in relation to the marine environment. Helgoländer wissenschalftliche Meeresuntersuchungen, 17, 247-256.

RADFORD, P. J., 1967. Growth analysis formulae - their use and abuse. Crop Science, 7, 171175 .

Raymont, J. E. G. \& ShIElds, J., 1962. Toxicity of copper and chromium in the marine environment. Advances in Water Pollution Research, 3, 275-290.

REES, W. J. \& RusselL, F. S., 1937. On rearing the hydroids of certain medusae, with an account of the methods used. Fournal of the Marine Biological Association of the United Kingdom, 22, 61-82.

RILEY, J.P. \& SkIRrow, G., 1971. Chemical Oceanography, vol. I. 712 pp. London: Academic Press. 
Roesijadi, G., Petrocelli, S. R., Anderson, J. W., Presley, B. J. \& Sims, R., 1974. Survival and chloride ion regulation of the porcelain crab Petrolisthes armatus exposed to mercury. Marine Biology, 27, 213-217.

RUSSELI HUNTER, W., 1949. The poisoning of Marinogammarus marinus by cupric sulphate and mercuric chloride. Fournal of Experimental Biology, 26, 113-124.

Schulz, H., 1888. Ueber Hefegifte. Pflügers Archiv für die gesamte Physiologie des Menschen und der Tiere, 42, 517-541.

SHAw, W. H. R., 1954. Toxicity of cations towards living systems. Science, New York, 120, $361-363$.

Shaw, W. H. R., 1961. Cation toxicity and the stability of transition-metal complexes. Nature, London, 192, 754-755.

Shaw, W. H. R. \& LowRANCE, B. R., 1956. Bioassay for the estimation of metal ions. Analytical Chemistry, 28, 1164-1166.

Smith, J. D., Nicholson, R. A. \& Moore, P. J., 1971. Mercury in water of the tidal Thames. Nature, London, 232, 393-394.

SMYth, H. F., 1967. Sufficient challenge. Food and Cosmetics Toxicology, 5, 51-58.

STARE, F. J., 1956. Arsenicals as growth promoters. Nutrition Reviews, 14, 206-209.

Stebing, A. R. D., 1971. Growth of Flustra foliacea (Bryozoa). Marine Biology, 9, 267-272.

Steeman Nielsen, E. \& Wium-Anderson, S., 1970. Copper ions as poison in the sea and in freshwater. Marine Biology, 6, 93-97.

TARDENT, P., 1963. Regeneration in the Hydrozoa. Biological Reviews, 38, 293-333.

Townsend, J. F. \& Luckey, T. D., 1960. Hormoligosis in pharmacology. Fournal of the American Medical Association, 173, 44-48.

Tusov, J. \& DAvis, L. V., 1971. Influence of environmental factors on the growth of Bougainvillia sp. In Experimental Coelenterate Biology (ed. H. M. Lenhoff, L. Muscatine and L. W. Davis), pp. 52-65. Honolulu: University of Hawaii Press.

WAGNER, F.S., 1969. Composition of the dissolved organic compounds in sea water: a review. Contributions in Marine Science, University of Texas, 14, 115-153.

WERnER, B., 1968. Polypengeneration und Entwicklungsgeschichte von Eucheilota maculata (Thecata, Leptomedusae). Helgoländer wissenschaftliche Meeresuntersuchungen, 18, 136-168.

WesternhageN, H. \& DethlefFEN, V., 1975. Combined effects of cadmium and salinity on development and survival of flounder eggs. Fournal of the Marine Biological Association of the United Kingdom, 55, 945-957.

Westernhagen, H., Dethlefsen, V. \& Rosenthal, H., 1975. Combined effects of cadmium and salinity on the development and survival of garpike eggs. Helgoländer wissenschaftliche Meeresuntersuchungen, 27, 268-282.

Westernhagen, H., Rosenthal, H. \& Spering, K.-R., 1974. Combined effects of cadmium and salinity on development and survival of herring eggs. Helgoländer wissenschaftliche Meeresuntersuchungen, 26, 416-433.

Wickens, J. F., 1972. The food value of brine shrimp, Artemia salina L., to larvae of the prawn, Palacmon serratus Pennant. Fournal of Experimental Marine Biology and Ecology, 10, 151-170.

Wilson, K. W., Coweli, E. B. \& BeYNoN, L. R., 1975. The toxicity testing of oils and dispersants: a European view. In Ecological Aspects of Toxicity Testing of Oil and Dispersants, pp. 129-141. London: Applied Science Publishers.

Wisely, B. \& Blick, R. A. P., 1967. Mortality of marine invertebrate larvae in mercury, copper and zinc solutions. Australian Fournal of Marine and Freshwater Research, 18, 63-72.

Woelke, C. E., 1965. Bioassay with bivalve larvae. Report. Pacific Marine Fisheries Commission, 18, 33-35.

YounG, L. G. \& Nelson, L., 1974. The effect of heavy metal ions on the mortality of sea urchin spermatozoa. Biological Bulletin. Marine Biological Laboratory, Woods Hole, Mass., 147, $236-246$. 